\title{
Article \\ Influence of Controlling Plasma Gas Species and Temperature on Reactive Species and Bactericidal Effect of the Plasma
}

\author{
Yuma Suenaga ${ }^{1}$, Toshihiro Takamatsu ${ }^{2,3, *(D)}$, Toshiki Aizawa ${ }^{1}$, Shohei Moriya ${ }^{1}$, Yuriko Matsumura ${ }^{4}$, \\ Atsuo Iwasawa ${ }^{4}$ and Akitoshi Okino ${ }^{1}$ (D)
}

1 Laboratory for Future Interdisciplinary Research of Science and Technology, Institute of Innovative Research, Tokyo Institute of Technology, J2-32, 4259 Nagatsuta, Midori-ku, Yokohama 226-8502, Japan; suenaga@plasma.es.titech.ac.jp (Y.S.); atoshiki@plasma.es.titech.ac.jp (T.A.); moriya@plasma.es.titech.ac.jp (S.M.); aokino@es.titech.ac.jp (A.O.)

2 Research Institute for Biomedical Sciences, Tokyo University of Science, 2669 Yamazaki, Noda 278-0022, Japan

3 Exploratory Oncology Research \& Clinical Trial Center, National Cancer Center, 6-5-1 Kashiwanoha, Kashiwa 277-8577, Japan

4 Division of Infection Prevention and Control, Tokyo Healthcare University, 4-1-17 Higashi-Gotanda, Shinagawa-ku, Tokyo 141-8648, Japan; y-matsumura@thcu.ac.jp (Y.M.); a-iwasawa@thcu.ac.jp (A.I.)

* Correspondence: totakama@east.ncc.go.jp

check for updates

Citation: Suenaga, Y.; Takamatsu, T.; Aizawa, T.; Moriya, S.; Matsumura, Y.; Iwasawa, A.; Okino, A. Influence of Controlling Plasma Gas Species and Temperature on Reactive Species and Bactericidal Effect of the Plasma. Appl. Sci. 2021, 11, 11674. https:// doi.org/10.3390/app112411674

Academic Editor: Bogdan-George Rusu

Received: 1 November 2021

Accepted: 6 December 2021

Published: 9 December 2021

Publisher's Note: MDPI stays neutral with regard to jurisdictional claims in published maps and institutional affiliations.

Copyright: (c) 2021 by the authors. Licensee MDPI, Basel, Switzerland. This article is an open access article distributed under the terms and conditions of the Creative Commons Attribution (CC BY) license (https:/ / creativecommons.org/licenses/by/ $4.0 /)$.

\begin{abstract}
In this study, plasma gas species and temperature were varied to evaluate the reactive species produced and the bactericidal effect of plasma. Nitrogen, carbon dioxide, oxygen, and argon were used as the gas species, and the gas temperature of each plasma was varied from 30 to $90{ }^{\circ} \mathrm{C}$. Singlet oxygen, $\mathrm{OH}$ radicals, hydrogen peroxide, and ozone generated by the plasma were trapped in a liquid, and then measured. Nitrogen plasma produced up to $172 \mu \mathrm{M}$ of the $\mathrm{OH}$ radical, which was higher than that of the other plasmas. In carbon dioxide plasma, the concentration of singlet oxygen increased from 77 to $812 \mu \mathrm{M}$, as the plasma gas temperature increased from 30 to $90{ }^{\circ} \mathrm{C}$. The bactericidal effect of carbon dioxide and nitrogen plasma was evaluated using bactericidal ability, which indicated the log reduction per minute. In carbon dioxide plasma, the bactericidal ability increased from 5.6 to 38.8 , as the temperature of the plasma gas increased from 30 to $90{ }^{\circ} \mathrm{C}$. Conversely, nitrogen plasma did not exhibit a high bactericidal effect. These results demonstrate that the plasma gas type and temperature have a significant influence on the reactive species produced and the bactericidal effect of plasma.
\end{abstract}

Keywords: atmospheric low-temperature plasma; reactive species; plasma disinfection

\section{Introduction}

In the conventional plasma applications, high-temperature (several thousand degrees Celsius or higher) atmospheric plasma and low-pressure (1/10,000 atm) nonthermal plasma have been used for analysis [1] and semiconductor manufacturing [2]. Recently, the stable generation of low-temperature plasma at approximately $50-100{ }^{\circ} \mathrm{C}$ under atmospheric pressure has become possible. This has significantly expanded the range of plasma applications. Applications of plasma, such as in disinfection [3] and hemostasis [4], wound healing [5], analysis of surface-adhesive compounds [6], and mobile on-site analytical devices [7], are examples that take advantage of the characteristics of atmospheric pressure and lowtemperature generation of plasma. A simple technique to improve the effectiveness of plasma treatment, such as surface treatment, involves increasing the energy input during plasma generation [8]. In atmospheric low-temperature plasmas, the gas temperature of the plasma is inevitably higher than room temperature $\left(15-25^{\circ} \mathrm{C}\right)$, because energy is supplied to the gas at room temperature through discharge to generate the plasma [9]. Therefore, for the treatment of plants and other particularly heat-sensitive processing targets, it is necessary to design a system that allows processing to be performed at a temperature that 
is close to room temperature. Ishihara et al. generated helium plasmas cooled with liquid nitrogen, and showed that it is possible to generate plasmas from cryogenic temperature to room temperature [10]. In addition, Oshita et al. reported a method to generate plasma at an arbitrary temperature by heating helium gas that is cooled by liquid nitrogen using a heater [11]. Although there are advantages to controlling plasma at low or room temperature to expand the range of applications, low- or room-temperature plasmas are not ideal for achieving certain processing effects. Kawano et al. investigated the influence of the gas temperature of helium plasma with oxygen on the bactericidal effect of plasma, and reported that it was enhanced by increasing the gas temperature of the plasma [12].

It has also been reported that the selection of the gas species in plasma is important for improving the treatment effect. Different plasma gas species produce different surface treatments and bactericidal effects, which affects the type and number of reactive species produced [13-15]. Yanagawa et al. reported the introduction of proteins into tobacco leaves via plasma treatment with various gas species, such as argon, nitrogen, oxygen, and carbon dioxide. In this process, liquid nitrogen is used to cool the gas temperature of the plasma, to avoid thermal damage to the plant [16]. Thus, the gas species and temperature of the plasma have a significant influence on the plasma treatment effect. Therefore, if the gas species and temperature of the plasma can be arbitrarily controlled, it is expected that the range of applications will expand, and the conditions of plasma treatment can be optimized to maximize the effect.

We have developed a multi-gas temperature-controllable plasma jet that can generate stable plasma with various gas species and control the gas temperature of the plasma. In this system, the plasmas can be generated with argon, helium, nitrogen, oxygen, carbon dioxide, or a mixture of these gases, and the gas temperature can be controlled in the range of $30-90{ }^{\circ} \mathrm{C}$. In this study, the liquid was treated with plasma, and the reactive species generated by each plasma gas species were evaluated. In addition, the effects of plasma gas species and temperature on the bactericidal effects of carbon dioxide and nitrogen plasmas were evaluated.

\section{Materials and Methods}

\subsection{Multi-Gas Temperature-Controllable Plasma Jet}

The developed multi-gas, temperature-controllable plasma jet can generate plasma with various gas species, such as carbon dioxide, argon, nitrogen, oxygen, and their mixtures, and the gas temperature of each plasma can be changed in the range of $30-90^{\circ} \mathrm{C}$. The plasma jet has two channels in its metal body: one for the temperature-control fluid, and the other for the plasma gas. The temperature of the metal body can be changed by flowing liquid at any temperature through the temperature-control fluid channel. The plasma gas temperature can be changed through heat exchange with the metal body. In this study, ethylene glycol, or $80 \mathrm{wt} . \%$ ethanol, was used as the temperature-control fluid for -30 to $20^{\circ} \mathrm{C}$, and tap water was used as the temperature-control fluid for $20-90{ }^{\circ} \mathrm{C}$. The temperature of the fluid was controlled using a thermostatic bath (NCB-1210B, TOKYO RIKAKIKAI CO, LTD., Tokyo Japan). In the plasma generation section, a voltage of $9 \mathrm{kV}$ and $16 \mathrm{kHz}$ was applied between the two electrodes to generate the plasma. The generated plasma flowed through a hole with a diameter of $1 \mathrm{~mm}$.

\subsection{Measurement of the Generated Reactive Species}

The concentration of the reactive species in the solution after plasma treatment was measured to determine the influence of the plasma gas species on reactive species' generation. In this experiment, $\mathrm{OH}$ radicals, singlet oxygen, ozone, and hydrogen peroxide were measured. The concentrations of $\mathrm{OH}$ radicals and singlet oxygen were measured using electron spin resonance (ESR; JES-FA100, JEOL Ltd., Tokyo, Japan). The concentrations of ozone and hydrogen peroxide were measured via a colorimetric method using a pocket ozonometer (DR300, Hach Company, Loveland, CO, USA) and double-beam spectrophotometer (U-2900, Hitachi High-Tech Science Corporation, Tokyo, Japan). An 
overview of the plasma treatment is shown in Figure 1. Nitrogen, carbon dioxide, oxygen, and argon plasma at $3 \mathrm{~L} / \mathrm{min}$ (standard) were used. The gas temperature of each plasma was controlled at $30,45,60,75$, and $90^{\circ} \mathrm{C}$ at a distance of $2 \mathrm{~mm}$ from the plasma outlet. Thereafter, $200 \mu \mathrm{L}$ of the solution was dispensed in a $10.3 \mathrm{~mm}$ diameter well, and treated from a height of $16.5 \mathrm{~mm}$ above the liquid surface for $15 \mathrm{~s}$.

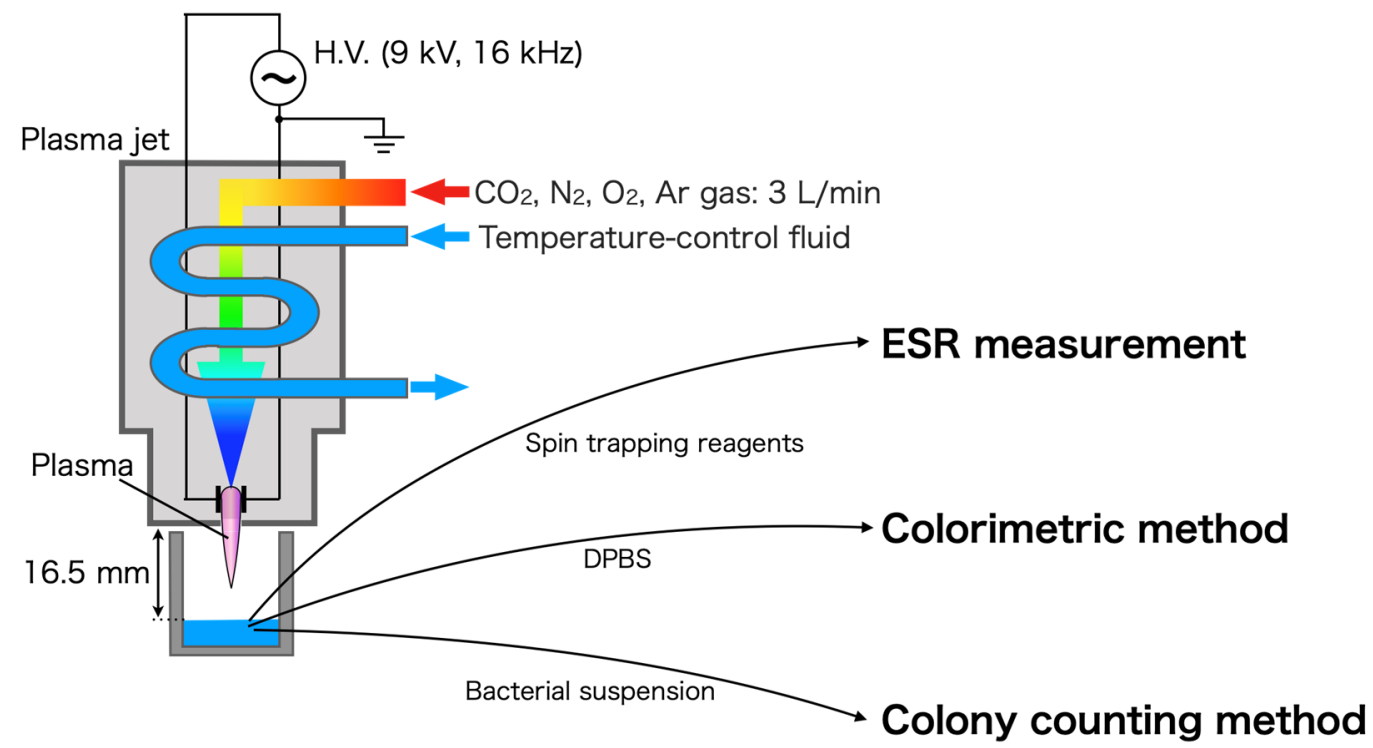

Figure 1. Overview of the plasma treatment.

The spin-trapping reagents for the $\mathrm{OH}$ radical and singlet oxygen were 5,5-dimethyl-1pyrroline-N-oxide (DMPO) [17] and 2,2,5,5-tetramethyl-3-pyrroline-3-carboxamide (TPC) [18]. These reagents were dissolved in Dulbecco's phosphate-buffered saline (DPBS) solution, and the concentrations of DMPO and TPC were fixed at 200 and $75 \mathrm{mM}$, respectively. Each $150 \mu \mathrm{L}$ of plasma-treated spin-trapping reagent was measured using ESR within $30 \mathrm{~s}$. The ESR measurement was set to a microwave frequency of $9.425 \mathrm{GHz}$, modulation frequency of $100 \mathrm{kHz}$, sweep time of $2 \mathrm{~min}$, magnetic field of $335.5 \pm 5 \mathrm{mT}$, and modulation width of $0.1 \mathrm{mT}$.

The colorimetric method with ozone reagent (AccuVac ${ }^{\circledR}$ Mid-Range 0-0.75 mg/L, Hach Company, Loveland, CO, USA) was used to measure the ozone. Plasma-treated $120 \mu \mathrm{L}$ of DPBS was immediately mixed with the ozone reagent, and the ozone concentration was determined using a pocket ozonometer. The hydrogen peroxide was also measured using the colorimetric method based on the reaction of $\mathrm{Fe}^{3+}$ with xylenol orange [19]. $\mathrm{Fe}^{3+}$ is a product formed by the reaction between $\mathrm{Fe}^{2+}$ and hydrogen peroxide. Plasma-treated $120 \mu \mathrm{L}$ of DPBS and $120 \mu \mathrm{L}$ of colorimetric reagent ( $200 \mu \mathrm{M}$ xylenol orange, $500 \mu \mathrm{M}$ ammonium ferrous sulfate, $50 \mathrm{mM}$ sulfuric acid, and $200 \mathrm{mM}$ sorbitol) were mixed. After 40 min of mixing, the hydrogen peroxide was quantified by measuring the absorbance at $586 \mathrm{~nm}$.

\subsection{Influence of Plasma Gas Temperature on Bactericidal Effect}

Disinfection using plasma, such as direct treatment and with plasma-activated liquids, has been reported [20,21]. In this study, we treated bacterial suspensions with temperaturecontrolled plasma, and evaluated their bactericidal effects. Staphylococcus aureus ATCC6538, the target of disinfection, was transferred to Luria-Broth agar medium on the day before the experiment, and incubated overnight at $36^{\circ} \mathrm{C}$. The bacterial suspensions were prepared by suspending Staphylococcus aureus in the DPBS solution to $10^{8} \mathrm{CFU} / \mathrm{mL}$. Carbon dioxide and nitrogen at $3 \mathrm{~L} / \mathrm{min}$ (standard) were used as the plasma gases. The plasma gas temperature was controlled at $30,45,60,75$, and $90^{\circ} \mathrm{C}$, at $2 \mathrm{~mm}$ from the plasma outlet. The bacterial suspension $(500 \mu \mathrm{L})$ was dispensed into a 24 -well plate (MS-8024R, Sumitomo Bakelite Co., 
Ltd., Tokyo, Japan), and the plasma was treated from $16.5 \mathrm{~mm}$ above the liquid surface. Subsequently, $100 \mu \mathrm{L}$ of the bacterial suspension was collected and diluted, and the number of surviving bacteria was evaluated using the colony counting method. For comparison, the bacterial suspension was treated with carbon dioxide and nitrogen gas at $90^{\circ} \mathrm{C}$, and the number of surviving bacteria was evaluated. In this case, temperature control using a chiller could not achieve $90^{\circ} \mathrm{C}$ gas without generating plasma. Therefore, the plasma jet body was directly heated using a ribbon heater, and the gas at $90{ }^{\circ} \mathrm{C}$ was generated by adjusting the voltage applied to the heater.

To quantitatively evaluate the bactericidal effect, we used the bactericidal activity $(B A)$ value, which can be calculated using Equation (1) [12]:

$$
B A=\frac{\log _{10}(N 1 / N 2)}{T 2-T 1}
$$

The $B A$ value indicates the number of bacteria inactivated per minute. It has been shown that plasma disinfection takes time after treatment, until the disinfection effect is achieved [22]. In this study, we evaluated the disinfection effect by calculating the $B A$ value from the time when the number of surviving bacteria decreased by more than one log reduction from the initial number to the time just before the number of bacteria decreased below the detection limit. Here, $T 1$ is the time at the measurement point just before the number of surviving bacteria decreased by more than one digit from the initial number, and $T 2$ is the time at the measuring point just before the number of surviving bacteria fell below the detection limit. The numbers of surviving bacteria at $T 1$ and $T 2$ are denoted as $N 1$ and $N 2$, respectively.

\section{Results}

\subsection{Measurement of Generated Reactive Species}

The relationship between the gas temperature of the plasma and the number of reactive species produced for each gas species is shown in Figure 2. The concentration of $\mathrm{OH}$ radicals was highest at approximately $130 \mu \mathrm{M}$ or more in the nitrogen plasma and at $20-40 \mu \mathrm{M}$ in the carbon dioxide and argon plasmas. The lowest concentration was detected in oxygen plasma at $10 \mu \mathrm{M}$ or less. In the nitrogen plasma, the concentration of $\mathrm{OH}$ radicals increased from 146 to $172 \mu \mathrm{M}$ with a change in the plasma gas temperature from 30 to $45^{\circ} \mathrm{C}$, showed an insignificant change from 45 to $75^{\circ} \mathrm{C}$, and decreased to $131 \mu \mathrm{M}$ with a change in temperature from 75 to $90^{\circ} \mathrm{C}$. In the carbon dioxide plasma, the concentration increased from 26 to $39 \mu \mathrm{M}$ with a change in the plasma gas temperature from 30 to $90{ }^{\circ} \mathrm{C}$. In the argon plasma, the concentration increased from 28 to $34 \mu \mathrm{M}$ with a change in the plasma gas temperature from 30 to $45^{\circ} \mathrm{C}$. There was almost no change in concentration when the plasma gas temperature increased from 45 to $75^{\circ} \mathrm{C}$, and the concentration decreased to $27 \mu \mathrm{M}$ with a change in the plasma gas temperature from 75 to $90^{\circ} \mathrm{C}$. In the oxygen plasma, the concentration increased from 5.7 to $10 \mu \mathrm{M}$ with a change in the plasma gas temperature from 30 to $90^{\circ} \mathrm{C}$.

The concentration of the singlet oxygen was higher in each plasma variant in the order of oxygen, carbon dioxide, nitrogen, and argon when the plasma gas temperature was $30^{\circ} \mathrm{C}$. A significant increase in concentration was observed in the carbon dioxide plasma above $45^{\circ} \mathrm{C}$. The concentration of the singlet oxygen in the carbon dioxide plasma increased from 77 to $459 \mu \mathrm{M}$, as the plasma gas temperature changed from 30 to $45^{\circ} \mathrm{C}$. From 45 to $60^{\circ} \mathrm{C}$, there was almost no change in the concentration, and from 60 to $90^{\circ} \mathrm{C}$, there was an increase in the concentration from 435 to $812 \mu \mathrm{M}$. In the oxygen plasma, the concentration increased from 96 to $208 \mu \mathrm{M}$ with a change in the plasma gas temperature from 30 to $90{ }^{\circ} \mathrm{C}$. In the nitrogen plasma, the amount produced increased from 56 to $115 \mu \mathrm{M}$ with a change in the plasma gas temperature from 30 to $90^{\circ} \mathrm{C}$. In the case of argon plasma, the amount produced increased from 16 to $24 \mu \mathrm{M}$ with a temperature change from 30 to $75^{\circ} \mathrm{C}$, and decreased to $13 \mu \mathrm{M}$ at $90^{\circ} \mathrm{C}$. 

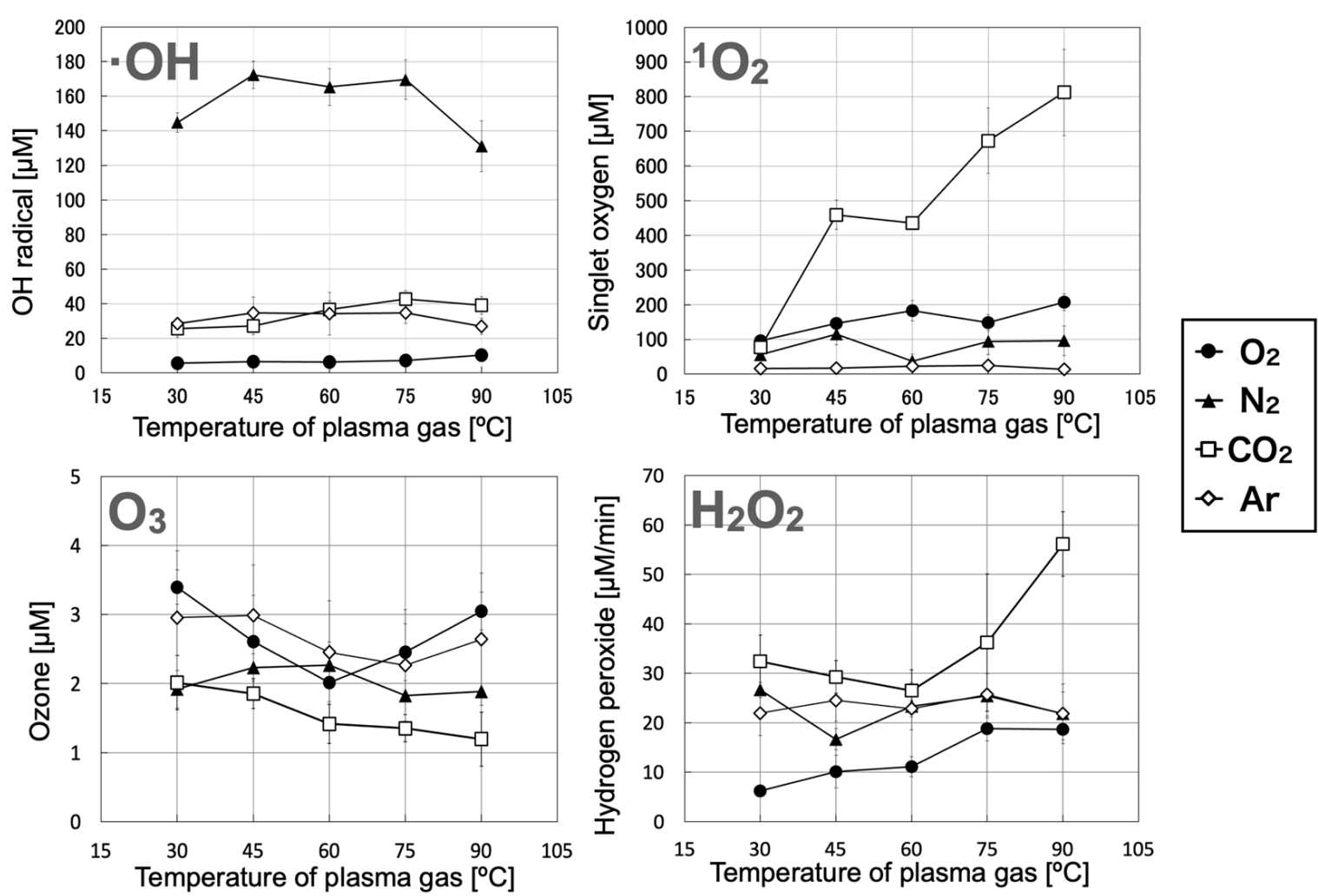

Figure 2. Influence of gas species and gas temperature of plasma on the generation of reactive species.

In the oxygen plasma, the concentration of ozone was $3.4 \mu \mathrm{M}$ at $30{ }^{\circ} \mathrm{C}$, reached a minimum of $2.0 \mu \mathrm{M}$ at $60^{\circ} \mathrm{C}$, and increased to $3.1 \mu \mathrm{M}$ as the temperature increased to $90{ }^{\circ} \mathrm{C}$. In the argon plasma, the concentration decreased slowly between 30 and $75^{\circ} \mathrm{C}$ from 3.0 to $2.3 \mu \mathrm{M}$, and then increased to $2.6 \mu \mathrm{M}$ at $90^{\circ} \mathrm{C}$. In the nitrogen plasma, the concentration was not significantly affected by the plasma gas temperature, and was $2.0 \pm 0.2 \mu \mathrm{M}$ between 30 and $90^{\circ} \mathrm{C}$. In the carbon dioxide plasma, the concentration decreased slowly from 2.0 to $1.2 \mu \mathrm{M}$ with a change in temperature from 30 to $90^{\circ} \mathrm{C}$.

The concentration of hydrogen peroxide was higher in the carbon dioxide plasma, similar to the argon and nitrogen plasmas, and lower in the oxygen plasma. In the carbon dioxide plasma, the concentration decreased from 32 to $26 \mu \mathrm{M}$ between 30 and $60{ }^{\circ} \mathrm{C}$, and increased significantly to $56 \mu \mathrm{M}$ as the gas temperature increased to $90^{\circ} \mathrm{C}$. In the nitrogen plasma, the concentration was almost constant between 30 and $90{ }^{\circ} \mathrm{C}$, but decreased to $17 \mu \mathrm{M}$ only at $45^{\circ} \mathrm{C}$. In the argon plasma, the change in the plasma gas temperature had an insignificant effect on the concentration, which remained constant at $21 \mu \mathrm{M}$. In the oxygen plasma, the concentration increased slowly from 6 to $19 \mu \mathrm{M}$ between 30 and $90{ }^{\circ} \mathrm{C}$.

\subsection{Influence of Plasma Gas Temperature on Bactericidal Effect}

Figure 3 shows the relationship between the gas temperature and bactericidal effects of the carbon dioxide and nitrogen plasmas. At a gas temperature of $30^{\circ} \mathrm{C}$, the carbon dioxide plasma showed a bactericidal effect of more than a 4-log reduction in the number of surviving bacteria in $60 \mathrm{~s}$. At a gas temperature of $45^{\circ} \mathrm{C}$, the carbon dioxide plasma demonstrated a bactericidal effect of more than a 6-log reduction in the number of surviving bacteria in $60 \mathrm{~s}$. At gas temperatures of 60 and $75^{\circ} \mathrm{C}$, the carbon dioxide plasma showed a bactericidal effect of more than a 6-log reduction in the number of surviving bacteria in $15 \mathrm{~s}$. At a gas temperature of $90^{\circ} \mathrm{C}$, the carbon dioxide plasma showed a bactericidal effect of more than a 6-log reduction in the number of surviving bacteria in $10 \mathrm{~s}$. The increase in the gas temperature of the plasma significantly increased its bactericidal effect. In the case of the carbon dioxide gas treatment at $90^{\circ} \mathrm{C}$, the number of surviving bacteria did not decrease by 1-log even after $60 \mathrm{~s}$ of treatment. The maximum bactericidal effect 
of the nitrogen plasma was only approximately a 1-log reduction after $60 \mathrm{~s}$ of treatment, showing a significant difference from the bactericidal effect of the carbon dioxide plasma. No difference in its bactericidal effect was observed when the plasma gas temperature was varied from 30 to $75^{\circ} \mathrm{C}$. In the case of the nitrogen gas treatment at $90{ }^{\circ} \mathrm{C}$, the number of surviving bacteria did not decrease by 1 -log even after $60 \mathrm{~s}$ of treatment.
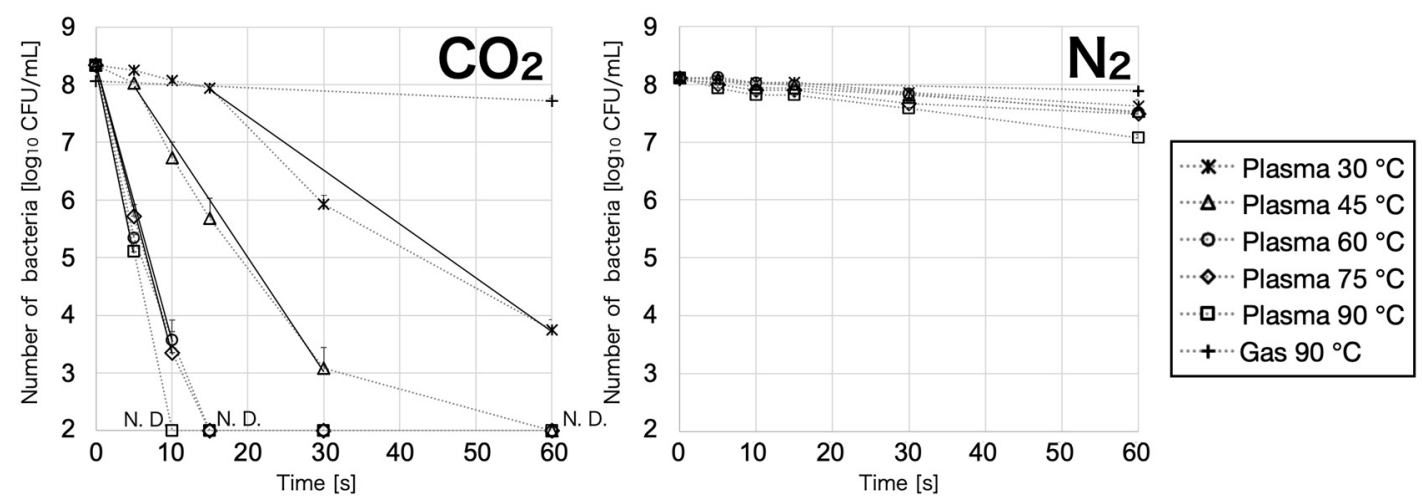

Figure 3. Relationship between the gas temperature and bactericidal effect of carbon dioxide and nitrogen plasma. In the left graph of the carbon dioxide treatment result, the solid black line shows the result used to calculate the $B A$ value. The slope represents the $B A$ value.

The $B A$ values that were calculated for the carbon dioxide plasma showed a significant bactericidal effect. The results are shown in Table 1 . The $B A$ value in the carbon dioxide plasma treatment increased with an increase in the plasma gas temperature. In the case of the plasma treatment at $90^{\circ} \mathrm{C}$, the $B A$ value increased by approximately seven times, compared to that at $30^{\circ} \mathrm{C}$.

Table 1. Relationship between the plasma gas temperature and $B A$ value.

\begin{tabular}{cccccc}
\hline Plasma Temp. $\left({ }^{\circ} \mathrm{C}\right)$ & $\mathbf{3 0}$ & $\mathbf{4 5}$ & $\mathbf{6 0}$ & $\mathbf{7 5}$ & $\mathbf{9 0}$ \\
\hline$B A$ value $\left(\mathrm{min}^{-1}\right)$ & 5.6 & 11.9 & 28.6 & 29.9 & 38.8 \\
\hline
\end{tabular}

\subsection{Relationship between Bactericidal Effect and Reactive Species in Carbon Dioxide Plasma}

The correlation coefficients between the bactericidal effect and number of reactive species produced in the carbon dioxide plasma were calculated. Figure 4 shows the relationship between the bactericidal effect and the number of reactive species produced. Table 2 shows the correlation coefficients for the bactericidal effects and reactive species. The amount of $\mathrm{OH}$ radicals produced was strongly and positively correlated with the bactericidal effect, with a correlation coefficient $(\mathrm{R})$ of 0.914 . The singlet oxygen production showed a strong positive correlation with the bactericidal effect, with an $\mathrm{R}$ value of 0.885 . The amount of ozone produced had a strong negative correlation with the bactericidal effect, with an $\mathrm{R}$ value of -0.997 . The amount of hydrogen peroxide produced was positively correlated with the bactericidal effect, with an $\mathrm{R}$ value of 0.623 .

Table 2. Correlation coefficient value (R) of $B A$ values and reactive species.

\begin{tabular}{|c|c|c|c|c|}
\hline & \multicolumn{4}{|c|}{ Correlation Coefficient Value, $\mathbf{R}$} \\
\hline & OH Radical & Singlet Oxygen & Ozone & Hydrogen Peroxide \\
\hline$B A$ value & 0.914 & 0.885 & -0.997 & 0.623 \\
\hline
\end{tabular}



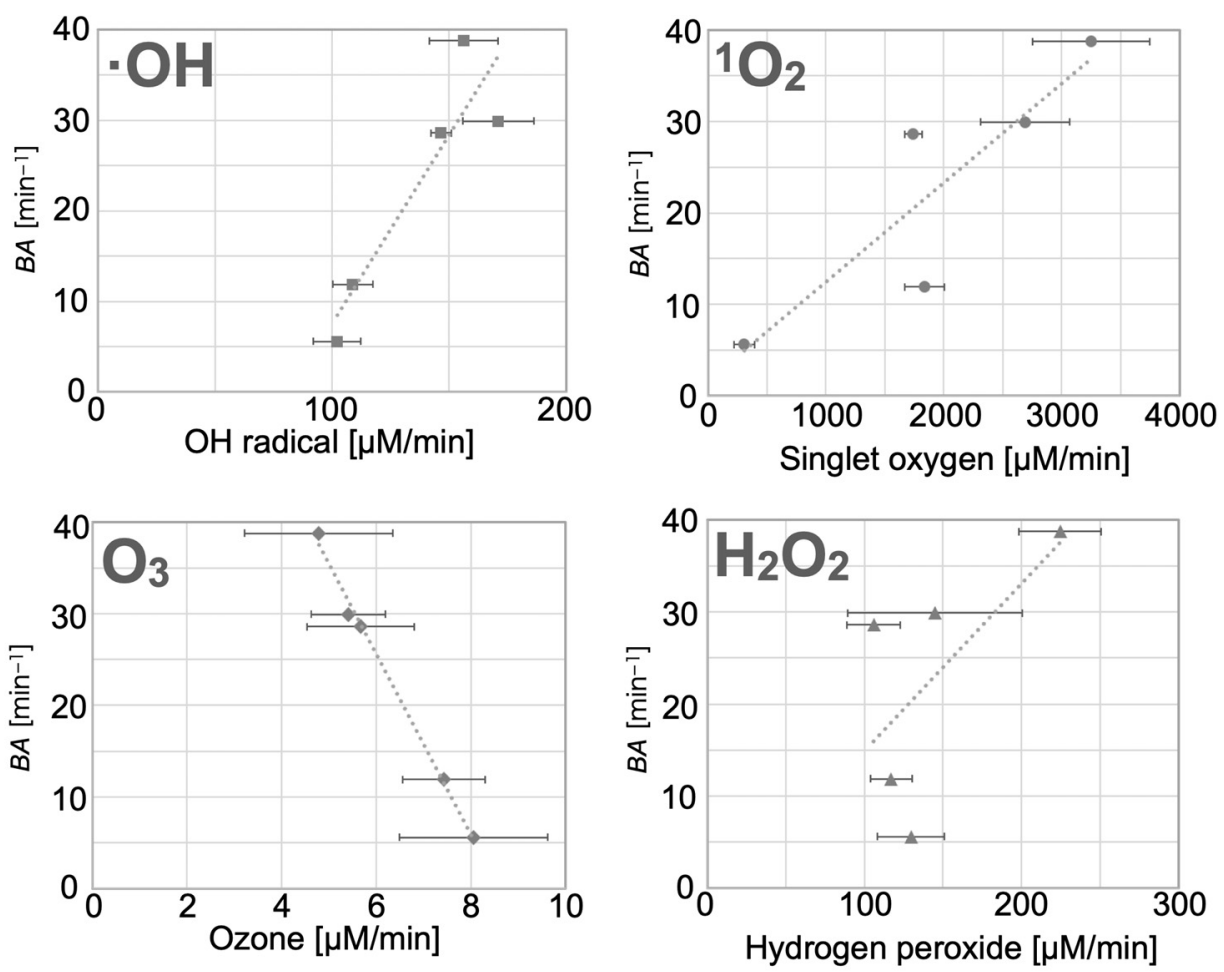

Figure 4. Correlation between bactericidal effect and reactive species in carbon dioxide plasma.

\section{Discussion}

As shown in Figure 2, the reactive species produced by the plasma were affected by varying the gas species and temperature. The $\mathrm{OH}$ radicals are produced largely from the nitrogen plasma. In the nitrogen plasma generated in the atmosphere, spectroscopic measurements have indicated the existence of nitrogen atoms [13]. The metastable atomic states of nitrogen $2^{2} \mathrm{D}_{5 / 2}$, argon $4^{3} \mathrm{P}_{2}$, and oxygen $2^{1} \mathrm{D}_{2}$ have lifetimes of $6.1 \times 10^{4} \mathrm{~s}$ [23], $56 \mathrm{~s}$ [24], and $1.0 \times 10^{2} \mathrm{~s}$ [23], respectively. It is thought that metastable nitrogen, which has a longer lifetime than other metastable atoms, remained active and contacted water or water droplets in the air, producing $\mathrm{OH}$ radicals at the gas-liquid interface [25]. In a previous study, we reported that more $\mathrm{OH}$ radicals were produced from nitrogen plasmas than from any other gas species [15]. Singlet oxygen was produced more in the highertemperature carbon dioxide plasma than in the oxygen plasma. This may be because, in the oxygen plasma, the atomic oxygen that produces singlet oxygen reacts with the ambient triplet oxygen, which is abundant, and quickly turns into ozone [26]. In fact, the amount of ozone produced by the oxygen plasma was higher than that produced by the carbon dioxide plasma.

In the oxygen and carbon dioxide plasmas, the production of $\mathrm{OH}$ radicals, singlet oxygen, and hydrogen peroxide tended to increase as the gas temperature increased. This is similar to the report by Kawano et al. on the increase in the production of the same reactive species when the gas temperature of the helium-oxygen mixture is increased [12]. In other words, the above-mentioned reactive species are considered to increase with increasing temperature in gas species that contain oxygen elements.

There was a significant difference in the bactericidal effect of the nitrogen and carbon dioxide plasmas, as shown in Figure 3, depending on the gas species. The nitrogen plasma showed only a weak bactericidal effect of less than 1-log reduction after $60 \mathrm{~s}$ of treatment. These results were different from our previous results, which confirmed the high bactericidal effect of nitrogen gas [14]. In the formation of reactive species in the nitrogen plasma, mixing with air is important because the gas does not contain oxygen. Therefore, it is considered that the difference in treatment conditions, such as gas flow rate and treatment distance, had a considerable influence. In contrast, the carbon dioxide plasma at $90{ }^{\circ} \mathrm{C}$ 
showed a high bactericidal effect of 6-log reduction after $10 \mathrm{~s}$ of treatment. In the treatment with the carbon dioxide gas at $90^{\circ} \mathrm{C}$, the number of surviving bacteria did not decrease by $1-\log$ even after $60 \mathrm{~s}$ of treatment. Therefore, these results indicate that the improvement in the bactericidal effect is not due to the gas temperature, but due to the introduction of reactive species generated by the plasma. In the carbon dioxide plasma, the production of reactive species, such as singlet oxygen and $\mathrm{OH}$ radicals, changed significantly as the plasma gas temperature increased, suggesting that these reactive species contribute to the bactericidal effect.

As shown in Table 2, the bactericidal effect of the carbon dioxide plasma exhibited a strong negative correlation with the ozone and a strong positive correlation with the $\mathrm{OH}$ radicals and singlet oxygen. Ozone is also used for disinfection, and Lezcano et al. reported 90\% disinfection of Escherichia coli by $0.94 \mathrm{mg} / \mathrm{L}(19.6 \mu \mathrm{M})$ of ozone in $0.41 \mathrm{~min}$ [27]. In our study, the highest ozone concentration in the carbon dioxide plasma was $2.0 \mu \mathrm{M}$, which is an insufficient concentration for disinfection. If the $\mathrm{OH}$ radical is assumed to be the reactive species contributing to its bactericidal effect, the observation is inconsistent with the fact that no bactericidal effect was observed in the nitrogen plasma. In our previous study, we investigated the bactericidal factor in the plasma treatment of carbon dioxide using a radical scavenger [14]. This study also suggested the contribution of singlet oxygen to the bactericidal effect, which is consistent with the results of the present study. These results suggest that the bactericidal effect of the carbon dioxide plasma is mainly due to the singlet oxygen. The bactericidal effect was improved by increasing the temperature, because the amount of singlet oxygen produced by the plasma increased with an increase in temperature, and the amount of singlet oxygen that contributed to the bactericidal effect in the liquid increased. However, in the disinfection of atmospheric low-temperature plasma, it has been reported that there are complex effects of reactive species, UV, and charged particles on microorganisms [28]; thus, singlet oxygen is not the only factor contributing to the bactericidal effect. In the future, other bactericidal factors should be investigated, such as reactive nitrogen species and $U V$, to clarify their contribution to the bactericidal effect.

\section{Conclusions}

In this study, plasma gas species and temperature were varied to evaluate the reactive species produced and the bactericidal effect of plasma. The reactive species produced by the plasma vary greatly depending on the gas species. It was found that a considerable amount of $\mathrm{OH}$ radicals were produced in the nitrogen plasma. Varying the plasma gas temperature resulted in a change in the concentration of the generated reactive species. In carbon dioxide plasma, the amount of singlet oxygen produced increased significantly with increasing temperature, and the amount of singlet oxygen produced was more than eight times greater at 90 than at $30{ }^{\circ} \mathrm{C}$. The bactericidal effects of nitrogen and carbon dioxide plasmas on Staphylococcus aureus in liquids were compared. The bactericidal effect of nitrogen plasma was not significantly affected by the temperature of the plasma gas. In the case of carbon dioxide plasma, the bactericidal effect was significantly improved by increasing the plasma gas temperature. The contribution of the singlet oxygen to the bactericidal effect of carbon dioxide was expected, based on the results of the bactericidal effect and reactive species produced.

It was also found that the effectiveness of the disinfection process could be improved by properly selecting the plasma gas species and temperature. This result can be attributed to the changes in the type and number of reactive species. Therefore, it is expected that the treatment effect can be improved by changing the plasma gas species and temperature in treatments other than disinfection, such as hemostasis, treatment of plants, and surface treatment. In the case of plasma treatment in air, mixing with ambient air is considered to have a significant effect on the generation of reactive species. To realize a more stable treatment, it is necessary to control the air mixing or to construct a treatment method that does not depend on air. To effectively control plasma gas species and temperature, it is necessary to understand the reactive species that contribute to the effect, and to study 
the conditions according to the purpose of each treatment. In the future, we will study other plasma applications, such as hemostasis and surface treatments, to improve the treatment effect and clarify the effect mechanism using changes in the plasma gas species and temperature.

Author Contributions: Conceptualization, S.M., T.T. and A.O.; methodology, Y.S., T.A., S.M., Y.M. and A.I.; validation, Y.S. and T.A.; formal analysis, Y.S.; investigation, Y.S., S.M., T.A., T.T. and Y.M.; resources, S.M., Y.M. and A.I.; data curation, Y.S., S.M., T.T. and Y.M.; writing—original draft preparation, Y.S.; writing—review and editing, S.M., T.T., Y.M., A.I. and A.O.; visualization, Y.S. and T.A.; supervision, T.T. and Y.M.; project administration, Y.M., A.I. and A.O.; funding acquisition, A.I. and A.O. All authors have read and agreed to the published version of the manuscript.

Funding: This study was supported by JSPS KAKENHI (Grant Number: 20K07039) and the Cooperative Research Project of the Research Center for Biomedical Engineering, National Cancer Center Research and Development Fund (Grant Number: 31-A-11), TERUMO LIFE SCIENCE FOUNDATION (Grant Number: 18-II106).

Institutional Review Board Statement: Not applicable.

Informed Consent Statement: Not applicable.

Data Availability Statement: The data that support the findings of this study are available from the corresponding author, T.T., upon reasonable request.

Acknowledgments: The authors would like to thank Ikuo Nakanishi at Quantum RedOx Chemistry Group, Institute for Quantum Life Science, Quantum Life and Medical Science Directorate, National Institutes for Quantum Science and Technology, for providing the measurement equipment for the electron spin resonance method. The authors would like to thank Norihiko Yamamoto at the Design and Manufacturing Division, Open Facility Center, Tokyo Institute of Technology, for preparing the plasma jet parts.

Conflicts of Interest: The authors declare no conflict of interest.

\section{References}

1. Taylor, H.E. Inductively Coupled Plasma-Mass Spectrometry: Practices and Techniques; Academic Press: Cambridge, MA, USA, 2000; pp. 1-5.

2. Kortshagen, U. Nonthermal plasma synthesis of semiconductor nanocrystals. J. Phys. D Appl. Phys. 2009, 42, 113001. [CrossRef]

3. Maisch, T.; Shimizu, T.; Li, Y.F.; Heinlin, J.; Karrer, S.; Morfill, G.; Zimmermann, J.L. Decolonisation of MRSA, S. Aureus and E. Coli by cold-atmospheric plasma using a porcine skin model in vitro. PLoS ONE 2012, 7, e34610. [CrossRef] [PubMed]

4. Nomura, Y.; Takamatsu, T.; Kawano, H.; Miyahara, H.; Okino, A.; Masaru, Y.; Takeshi, A. Investigation of blood coagulation effect of nonthermal multigas plasma jet in vitro and in vivo. J. Surg. Res. 2017, 219, 302-309. [CrossRef] [PubMed]

5. Shimatani, A.; Toyoda, H.; Orita, K.; Hirakawa, Y.; Aoki, K.; Oh, J.; Shirafuji, T.; Nakamura, H. In vivo study on the healing of bone defect treated with non-thermal atmospheric pressure gas discharge plasma. PLoS ONE 2021, 16, e0255861. [CrossRef] [PubMed]

6. Aida, M.; Iwai, T.; Okamoto, Y.; Miyahara, H.; Seto, Y.; Okino, A. Development of an ionization method using hydrogenated plasma for mass analysis of surface. J. Anal. At. Spectrom. 2018, 33, 578-584. [CrossRef]

7. Iwai, T.; Kakegawa, K.; Aida, M.; Nagashima, H.; Nagoya, T.; Kanamori-kataoka, M.; Miyahara, H.; Seto, Y.; Okino, A. Development of a gas-cylinder-free plasma desorption/ionization system for on-site detection of chemical warfare agents. Anal. Chem. 2015, 87, 5707-5715. [CrossRef]

8. Van Deynse, A.; Cools, P.; Leys, C.; De Geyter, N.; Morent, R. Surface activation of polyethylene with an argon atmospheric pressure plasma jet: Influence of applied power and flow rate. Appl. Surf. Sci. 2015, 328, 269-278. [CrossRef]

9. Yoshimura, S.; Aramaki, M.; Otsubo, Y.; Yamashita, A.; Koga, K. Controlling feeding gas temperature of plasma jet with Peltier device for experiments with fission yeast. Jpn. J. Appl. Phys. 2019, 58, SEEG03. [CrossRef]

10. Ishihara, D.; Noma, Y.; Stauss, S.; Sai, M.; Tomai, T.; Terashima, K. Development of a dielectric barrier discharge (DBD) cryo-microplasma. Plasma Sources Sci. Technol. Dev. 2008, 17, 035008. [CrossRef]

11. Oshita, T.; Kawano, H.; Takamatsu, T.; Miyahara, H.; Okino, A. Temperature controllable atmospheric plasma source. IEEE Trans. Plasma Sci. 2015, 43, 1987-1992. [CrossRef]

12. Kawano, H.; Takamatsu, T.; Matsumura, Y.; Miyahara, H.; Iwasawa, A.; Okino, A. Influence of gas temperature in atmospheric non-equilibrium plasma on bactericidal effect. Biocontrol Sci. 2018, 23, 167-175. [CrossRef] [PubMed]

13. Takamatsu, T.; Hirai, H.; Sasaki, R.; Miyahara, H.; Okino, A. Surface hydrophilization of polyimide films using atmospheric damage-free multigas plasma jet source. Kagaku Kogaku Ronbunshu 2013, 39, 372-377. [CrossRef] 
14. Takamatsu, T.; Uehara, K.; Sasaki, Y.; Hidekazu, M.; Matsumura, Y.; Iwasawa, A.; Ito, N.; Kohno, M.; Azuma, T.; Okino, A. Microbial inactivation in the liquid phase induced by multigas plasma jet. PLoS ONE 2015, 10, e0132381. [CrossRef]

15. Takamatsu, T.; Uehara, K.; Sasaki, Y.; Miyahara, H.; Matsumura, Y.; Iwasawa, A.; Ito, N.; Azuma, T.; Kohno, M.; Okino, A. Investigation of reactive species using various gas plasmas. RSC Adv. 2014, 4, 39901-39905. [CrossRef]

16. Yanagawa, Y.; Kawano, H.; Kobayashi, T.; Miyahara, H.; Okino, A.; Mitsuhara, I. Direct protein introduction into plant cells using a multi-gas plasma jet. PLoS ONE 2017, 12, e0171942. [CrossRef] [PubMed]

17. Kohno, M.; Yamada, M.; Mitsuta, K.; Mizuta, Y.; Yoshikawa, T. Spin-trapping studies on the reaction of iron complexes with peroxides and the effects of water-soluble antioxidants. Bull. Chem. Soc. Jpn. 1991, 64, 1447-1453. [CrossRef]

18. Matsumura, Y.; Iwasawa, A.; Kobayashi, T.; Kamachi, T.; Ozawa, T.; Kohno, M. Detection of high-frequency ultrasound-induced singlet oxygen by the ESR spin-trapping method. Chem. Lett. 2013, 42, 1291-1293. [CrossRef]

19. Ikai, H.; Nakamura, K.; Kanno, T.; Shirato, M.; Meirelles, L.; Sasaki, K.; Niwano, Y. Synergistic effect of proanthocyanidin on the bactericidal action of the photolysis of $\mathrm{H}_{2} \mathrm{O}_{2}$. Biocontrol Sci. 2013, 18, 137-141. [CrossRef] [PubMed]

20. Abonti, T.R.; Kaku, M.; Kojima, S.; Sumi, H.; Kojima, S.; Yamamoto, T.; Yashima, Y.; Miyahara, H.; Okino, A.; Kawata, T.; et al. Irradiation effects of low temperature multi gas plasma jet on oral bacteria. Dent. Mater. J. 2016, 35, 822-828. [CrossRef]

21. Pan, J.; Li, Y.L.; Liu, C.M.; Tian, Y.; Yu, S.; Wang, K.L.; Zhang, J.; Fang, J. Investigation of cold atmospheric plasma-activated water for the dental unit waterline system contamination and safety evaluation in vitro. Plasma Chem. Plasma Process. 2017, 37, 1091-1103. [CrossRef]

22. Lee, M.H.; Park, B.J.; Jin, S.C.; Kim, D.; Han, I.; Kim, J.; Hyun, S.O.; Chung, K.H.; Park, J.C. Removal and sterilization of biofilms and planktonic bacteria by microwave-induced argon plasma at atmospheric pressure. New J. Phys. 2009, 11, 115022. [CrossRef]

23. Smirnov, B.M. Excited Atoms. In Physics of Atoms and Ions, 1st ed.; Springer: New York, NY, USA, $2003 ;$ p. 148.

24. Small-Warren, N.E.; Chiu, L.-Y.C. Lifetime of the metastable $3 \mathrm{P}_{2}$ anti ${ }^{3} \mathrm{P}_{0}$ states of rare-gas atoms. Phys. Rev. A 1975, 11, 1777-1783. [CrossRef]

25. Herron, J.T.; Green, D.S. Chemical kinetics database and predictive schemes for nonthermal humid air plasma chemistry. Part II. Neutral species reactions. Plasma Chem. Plasma Process. 2001, 21, 459-481. [CrossRef]

26. Laroussi, M.; Leipold, F. Evaluation of the roles of reactive species, heat, and UV radiation in the inactivation of bacterial cells by air plasmas at atmospheric pressure. Int. J. Mass Spectrom. 2004, 233, 81-86. [CrossRef]

27. Lezcano, I.; Rey, R.P.; Baluja, C.; Sánchez, E. Ozone inactivation of Pseudomonas Aeruginosa, Escherichia Coli, Shigella Sonnei and Salmonella Typhimurium in water. Ozone Sci. Eng. 1999, 12, 293-300. [CrossRef]

28. Guo, J.; Huang, K.; Wang, J. Bactericidal effect of various non-thermal plasma agents and the influence of experimental conditions in microbial inactivation: A review. Food Control 2015, 50, 482-490. [CrossRef] 